\section{Questión}

Periodismo / Comunicación ISSN 1669-6581
- Av. $44 \mathrm{~N}^{\circ} 676,1^{\circ}$ piso

CP 1900 - La Plata - Argentina

www.perio.unlp.edu.ar/question

Limbo Perfecto

Susana Martins

DOI: https://doi.org/10.24215/16696581e337

\title{
Limbo Perfecto
}

\section{Perfect Limbo}

Susana Martins / smartins1074@gmail.com Comunicadora Social. Docente e Investigadora

Brillaba, era una perla Y nunca hacía nada. El tiempo, maldita daga, Lamiéndonos los pies.

Polaroid de locura ordinaria - Fito Páez

Fue un golpe seco. Veníamos con la inercia que da la aceleración de los días y de un momento a otro el mundo se detuvo. Literal. Para muches. En todas partes. Para siempre. O para nunca. Esos modos de nombrar el tiempo perdieron sentido. A la fantasía de la linealidad y los proyectos para adelante se opuso la realidad de la circularidad. Hace días que nos movemos en círculos. $Y$ los planes han quedado suspendidos en un limbo que parece tener principio, pero no fin. Ya no nos preguntamos cuándo sino cómo. ¿Cómo será volver? ¿Dónde vamos a volver? Quizás también ¿desde dónde vendremos? Porque como en las series de ciencia ficción, el demogorgon está ahí fuera. Y no es gigante ni viscoso. Es microscópico y letal. El Estado regulador de las conductas ciudadanas nos ha obligado al confinamiento. No podemos salir. No podemos encontrar las armas con las cuales destruir al monstruo. Entonces sólo nos queda preservarnos de él. $Y$ de les otres y de ¿nosotres? El golpe seco nos aturde y nos inmoviliza. 
Cuarenta días de parálisis. Cuarenta noches de sospecha. ¿Quiénes éramos antes? ¿En cuánto se mide la resiliencia? ¿Cuánto falta para explotar?

Hagamos de cuenta que hacemos de cuenta que no pasa nada. Como el juego de les niñes. Hagamos como que esta es nuestra casa y yo soy la mamá y vos la hija. Vos me hacés caso cuando te pido que hagas la tarea. $Y$ ordenás tu habitación cuando jugamos a que yo te pido que ordenes la habitación. Funciona. Un día, dos, tres...Después no funciona. No quiero jugar más.

Voy a hacer como que cocino. Hoy, pastas. Caseras. Con esmero. A la tarde, torta y panqueques. Mañana voy a probar si me sale el pan casero. El sábado, pizzas de distintos sabores. El domingo, asado. ¿Cuándo es domingo? ¿Qué importa? Ya cociné. Ya tejí. Ya sembré. Ya grité. No quiero jugar más.

Del alivio de no tener horarios ni obligaciones ni consecuencias pasamos a buscar desesperadamente rutinas que nos ordenen un poco los horarios y nos recuerden por qué es importante levantarse. Confinados al mundo de lo privado ponemos nuestras reglas. Pero la fiesta puede convertirse rápidamente en tedio.

¿Cuántos libros puedo leer? ¿Cuántas películas mirar? ¿Cuántas tesis escribir? ¿Cuántas tartas inventar? Todo lo que nos narcotice está bien. Lo que necesitamos es dejar de pensar que el tiempo se va inexorablemente y nuestros cuerpos están condenados a una quietud siniestra que nos enfrenta a la irremediable pregunta de quiénes somos y cómo vamos a hacer para sobrevivir.

Lo que necesitamos desesperadamente es dejar de pensar.

$Y$ permitirnos transcurrir.

Lo que pone en evidencia la excepción es el carácter ficcional de lo que hasta hace unos días llamamos vida.

Lo que pone en evidencia la quietud es la mentira de la velocidad. Correr para no llegar a ningún lado porque en algún momento aprendimos que mostrarnos actives es un capital social. Asumimos el ritmo del entorno frenético porque buscamos pertenecer al mundo de les vives exitoses. No de les que la miran pasar. No de les contemplatives que esconden en su filosofía barata el inefable carácter de su fracaso. Nos envolvemos en la dinámica de los rituales laborales para acumular éxitos cuantificables por sistemas perversos a los que insultamos en voz baja y nunca nos animamos a desafiar. 
Lo que pone en evidencia el limbo es que no somos imprescindibles. Peor: ni siquiera necesaries. $Y$ todo lo que hemos construido para darle sentido a la anodina existencia se reduce a tres cosas simples que nos entran en una cajita: un abrazo apretado, el viento en la cara, una canción.

Lo demás, evidentemente, sobra.

Rodeados de muerte nos enfrentamos a la realidad de la finitud. Invadidos de miedo, inventamos excusas para negar el peso de lo evidente: que, lentamente, nos estamos extinguiendo. 